\title{
A CONVERGENCE OF GENRES: GOTHIC AND SCIENCE FICTION IN FRANKENSTEIN
}

Ismael Bernardo Pereira ${ }^{1}$

This article aims to analyze the novel Frankenstein, by Mary W. Shelley, from a perspective of literary genres. The work is believed to manifest both traits of the Gothic genre-due to its structure and common themes to the period it was published-and of what would in future be called the Science fiction genre. Those elements are here observed, in the novel as well as in the context of its creation. In this sense, there is a convergence of genres taking place, albeit one of them is in its nascent form: Shelley's novel antecipate a scientific interest that would be specified in later fiction, being derived from her legacy. Tzvetan Todorov's perspective is considered, inasmuch as he defends the presence of multiple genres inside a work of fiction, as well as the creation of new literary genres from other, pre-existent, ones. It is concluded that the novel manifests enough elements to comprise both the genres here discussed, with its common and different traits.

Frankenstein. Gothic. Science Fiction. literary genres.

\section{INTRODUCTION}

One of the core works in $19^{\text {th }}$ century English fiction, Frankenstein has gained the status of a modern myth (BALDICK, 1987). The constant adaptations of its main formula to other books, movies, among other media, justifies this label of an ever-changing narrative. And although each new appropriation tends to add something new to the scientist-creature dialogue and the pessimistic view of science - or its mishadling by men, depending on the interpretation- Mary Shelley's work tend to be identified as the starting point behind an entire tradition. Frankenstein ends up not only finding its roots in Gothic fiction, with its suspenseful structure of multiple narrators and an apparently supernatural being; it is also often considered the first book of what would later be called Science fiction (KINKAID, 2008), since it deals with scientific principles within a scientific world.

This article does not intend to state such definite assumptions about the origin of the Sci-fi genre though. On the contrary, the objective is to establish genres as constantly evolving structures, which are simply born from other genres, as well as consider the presence of multiple genres in the same text, as stated by Tzvetan Todorov (1976; 1975). Thus, the representation of both genres, Gothic and Science fiction, will be analyzed, according to their conventions. A special care will be given to the genesis of the novel, since it reveals much about the context of

\footnotetext{
${ }^{1}$ Mestre em Literaturas de Língua Inglesa pelo curso de Sociedade, (Inter) Textos Literários e Tradução nas Literaturas Estrangeiras Modernas, pela Universidade Federal do Rio Grande do Sul. Email: ismael.bernardo.pereira@hotmail.com
} 
its creation and its intentions. Afterward, Mary Shelley's book will be related to posterior important appropriations of its formula, in order to visualize the progression of the genres mentioned previously within the Frankenstein tradition. Finally, a brief discussion will intend to place the novel within a convergence of genres, which would influence the future of a literary perception.

It is believed that Frankenstein's importance is not undermined by not placing it as the starting-point of Sci-fi. Instead of only looking for how the book antecipates a single genre, it is expected that an analysis of the contribution of Gothic will bring more light to the discussion of Frankenstein's place and influence in literature, a place perhaps not even conceived by its author. Her "hideous progeny" (SHELLEY, 2005, p. 358), prospered to a level of creating perhaps the most recognizable figure-be it the Monster, or "Frankenstein", as it is often mistakenly called-in fiction as whole.

\section{FRANKENSTEIN AND THE GOTHIC TRADITION}

Frankenstein was first published in 1818, two years after the fateful summer of its first conception. Based on the diaries of the parties involved, several other authors have reconstructed the stormy day of 1816, in which Mary Shelley, her stepsister Clair Clairmont, her husband and poet Percy Shelley, the poet Lord Byron and the doctor and aspiring writer John Polidori gathered in Vila Diodati, a rented house in Geneva, to discuss science and ghost stories. From this information about the genesis of the book, the duplicity of genres is already visible - the union of science to Ghotic/ghost patterns-; but for now, it is important to examine the amount of Gothic traits surrounding the environment which contributed for the book's tone.

Having gathered inside Byron's house, due to the stormy weather, Byron resolves to read to the group a story from the book Fantasmagoriana, or a Collection of the Histories of Apparitions, Spectres, Ghosts, etc., in which a husband discovers that her wife turned into a corpse (FLORESCU 1998). After a discussion relating the scientific probabilities of animation, Byron proposes a challenge in which every one there should write a ghost story, what is accepted, since, besides Percy Shelley and Byron—-the great poets of the group-the other 
members also had the habit of writing. In her Preface to the third edition of Frankenstein, Mary Shelley reveals her feelings in face on the task of writing that which would turned out to be the most successful book to spring from that Summer:

\begin{abstract}
I busied myself to think of a story, - a story to rival those which had excited us to this task. One which would speak to the mysterious fears of our nature, and awaken thrilling horror - one to make the reader dread to look round, to curdle the blood, and quicken the beatings of the heart. If I did not accomplish these things, my ghost story would be unworthy of its name. (SHELLEY, 2005, p. 355-56)
\end{abstract}

Shelley intended to create, according with her description, a classic Gothic story as they where understood in her time, which tended, according to Eve Kosofsky Sedgwick, to "point somehow toward an aesthetic based on pleasurable fear" (1986, p. 11). Despite some innovations which will be later discussed, Frankenstein is usually placed within the tradition of the "group of novels written between the 1760s and the 1820s" (PUNTER, 2013, p. 1), the most regonizable Gothic works when the genre is called out, such as Horace Walpole's The Castle of Otranto, Ann Radcliffe's The Mysteries of Udolpho, Matthew Lewis' The Monk, among others. All of this books were read by Mary Shelley, in the years previous to the writing of her work (FLORESCU, 1998), hence the possibility of assuming their influence, besides the obvious proximity with Percy Shelley and Lord Byron, romantic writers who busied themselves in Gothic themes.

Mary's personal anxieties may also have contributed to the themes of life and creation present in her book. At the moment of the writing, she had already lost her first baby, Mary Jane, who would come back to her in a recurring dream (SCHOR, 2003). Besides the natural connection of reanimation that may reflect the author's possible desire in life reflected to her work, another constant theme of the Gothic is reflected. Victor Frankenstein intends to "give birth" to a being outside the natural forms of conception, which can be translated as the repression of sexual desire, albeit Shelley diverges from the Gothic tradition for having a male, and not a heroine, as a protagonist. Such sexual repression can also be perceived in Victor's refusal of creating a female creature to his Monster, as well as in the Monster's revenge toward Elizabeth, who never is sexually fulfilled in her wedding night. 
Following Sedgwick treatment of Gothic in her The Coherence of Gothic Conventions, it is possible to find many other Gothic traits in Frankenstein. The author explains, for example, the relation between the self and something that should belong to it, but is ultimately separated by some kind of barrier (1986). This can be perceived in Victor's separation from his ambitions by the norms and morals of society; when he breaks through it, he is again separated, now from his peace with Elizabeth by the Monster he created. Still on the matter of belonging, the concept of the double can also be brought to light once Frankenstein and the Monster are seen as extensions of one another. George Levine, in analysing the elements of Frankenstein's metaphor, notes this aspect: "Frankenstein's obsession with science is echoed in the Monster's obsession with destruction. The two characters haunt and hunt each other through the novel, each evoking from us sympathy for their sufferings, revulsion from their cruelties" (1982, p. 15). Complementing, Otto Rank, a writer who also developed the term, states that the impulse of destruction makes the double's life intimately related to that of the other person (loc. 257-60). That is visible throughout the narrative in both of the character's speech, but especially in the Monster's final realization of his destiny once Frankenstein is finally dead: "'That is also my victim!' he exclaimed: 'in his murder my crimes are consummated; the miserable series of my being is wound to its close!'" (Shelley, 2005, p. 240).

Sedgwicks also points the aspect of the unspeakable as an important feature of the Gothic. The most clear example of this aspect is the moment in which Victor beholds his finished creation and, speechless, abandons him:

\footnotetext{
How can I describe my emotions at this catastrophe, or how delineate the wretch whom with such infinite pains and care I had endeavoured to form? (...) I had desired it with an ardour that far exceeded moderation; but now that I had finished it, the beauty of the dream had vanished, and breathless horror and disgust filled my heart. (Shelley, 2005, p. 85)
}

The unspeakable, the surprise of beholding the Creature coming to life is the action which puts all the further conflicts of the narrative in motion. Should Frankenstein had stopped and taken care of his creature, despite its wretchedness, perhaps the double figures would be just one, and consequently would not enter into conflict. In a way related to this aspect of unspeakable is the own structure of the narrative, described by Sedgwick as "a story within a story 
within a story within a story." (1986, p. 19) In Frankenstein there are three narrators-Walton, Victor and the Monster-and as a consequence, three levels of narrative information. The Monster's story, the most inner story in the middle of the book, is actually Walton's perception of Victor's perception of what he heard the monster speak, in the same way that Victor's narrative is subject to Walton's perception. This sort of structure not only filter reinforces the unspeakable in the narrative, as no character gets to know the enteirity of the story, but also constributes for the suspense which surrounds the book. The reader has always to wait for something to happen: Walton's narrative gives a glimpse of the pursuit between Frankenstein and the Monster, which would only unfold at the very end, for example.

Mary Shelley's novel, due to the influence of its conception and based on some of the characteristics shown here, can surely be placed within the Gothic tradition. The point this article inteds to make, however, is that, besides representing Gothic structures, Frankenstein also carries a number of innovations which enable the creation of a new genre, later to be called Science fiction. The relation between the two genres is very close, as one represent the development of some of the characteristics of the other, at the same time that there are important differences between them, once several examples of the genres are considered.

\section{GOTHIC AND SCIENCE FICTION: A DIALOGUE}

Despite the several conventions presented previously, when looking to the history of the works which received the label of Gothic, consistent differences are noticed. From The Castle of Otranto and its medieval scenery, through Frankenstein and the beginning of scientific interest, to the Brontë Sisters and the psychological approach to the role of women; there are many sides to the same genre. James Watt, in his book Contesting the Gothic, acknowledges that the genre is a modern construct whose categorization do not do justice to its diversity:

Though the genre of the Gothic romance clearly owes its name to the subtitle of The Castle of Otranto's second edition, 'A Gothic Story', the elevation of Walpole's work to the status of an origin has served to grant an illusory stability to a body of fiction which is distinctly heterogeneous. 
(...) any categorization of the Gothic as a continuous tradition, with a generic significance, is unable to do justice to the diversity of the romances which are now accommodated under the 'Gothic' label, and liable to overlook the often antagonistic relations that existed between different works or writers. (WATT, 2004, p. 1)

In the same sense, David Punter proposes two interpretations about the development of the Gothic, "as a historically delimited genre or as a more wideranging and persistent tendency within fiction as a whole" (2013, p. 12). Robert Heilman, in his famous paper "Charlotte Brontë's 'New' Gothic", argues that Charlotte "finds new ways to achieve the ends served by old Gothic", focusing on "the intensification of feelings" (1967, p. 121). The authors do not intend to argue that the genre had turned into something else entirely: the point is that it tented to change, focusing on new aspects as time went by, at the same time that some essential conventions of the genre were kept untouched-such as the sensation of fear and the questioning of the current order through the irrational, for example.

In the case of Frankenstein, we can still perceive the supernatural, the apparently irrational and, consequently, fear; but now there is an attempt of selfknowledge through rational, i. e., scientific, means. What would seem a complete contradiction within the genre's purpose still contributes to its main effect. The reader is no less terrified at Frankenstein's Monster because it is a product of scientific rationaility. Rather the opposite is true: the fact that human knowledge could evolve to attempt the creation of such creature seems more frightening than some imaginary ghost. And at the same time that Gothic is still alive in Mary Shelley's novel, the entire treatment of science-a scientific environment, the use, though subtle, of scientific principles to be extrapolated, and the pessimistic tone-are sufficient to initiate, and influence, the tendency of Science fiction.

Although in the end of the nineteenth-century the expression "scientific romances" was already popular, especially through H. G. Wells, Science fiction, or rather, the "Scientifiction" concept was first devised by editor Hugo Gernsback in the first edition of the Amazing Stories magazine in 1926. The publication was the first magazine to publish only such works described with this label, "the Jules Verne, H. G. Wells, and Edgar Allan Poe type of story-a charming romance intermingled with scientific fact and prophetic vision" (1926, p. 3). The first editions helped to create a tradition of Sci-fi republishing famous nineteenth-century authors as the above mentioned, while also influencing people to write new 
twentieth-century versions with certain innovations (James; Mendlesohn, 2003, p. 45). Several other concepts for the genre, by authors and critics alike, were followed. Perhaps the most often quoted definition, either to be accepted or refuted, is Darko Suvin's "cognitive strangement":

\begin{abstract}
SF is, then a literary genre whose necessary and sufficient conditions are the presence and interaction of estrangement and cognition, and whose main formal device is an imaginative framework aternative to the author's empirical environment. The estrangement differentiates it from the "realistic" literary mainstream of 18th to 20th century. The cognition differentiates it not only from myth, but also from the fairy tale and the fantasy. (SUVIN, 1972, p. 375)
\end{abstract}

While Gernsback concise statement of "scientific fact and prophetic vision" fits precisely in Frankenstein's structure-taking prophetic both to the realm of fiction to reality-Suvin's, although broad concept, tend to exlude Shelley's novel from some of its intrisic aspects, as the status of a modern myth, besides the fact that the "cognition" there is still very subtle. This happens to be no exception, but the general rule. Science fiction grew to be so much varied, due to diverse interpretations of what the genre could grasp, that an indefinite number of books, sometimes apparently alien to one another, ended up sharing the same label, such as extraordinary voyages, utopias/dystopias, hard-sci-fi, etc. In this sense, the establishment of a single concept of the genre, which could comprehend the entireity of its manifestations, is proven a difficult task.

Paul Kinkaid's approach to Sci-fi, and in a sense to genres as a whole, proves to be a good alternative. The author argues that there's no specific starting point for Science fiction, since "there is no ancestral text that could possibly contain, even in nascent form, all that we have come to identify as science fiction" (2008, p. 13). If Frankenstein, for example, was identified as such founder workas it often is-every other work of fiction which intended to belong to the genre would have to conform to its laws. In order to avoid such limitations, Kinkaid treats the Sci-fi genre as "a web of resemblances":

And any number of those resemblances might constitute what we would call science fiction. By thinking of science fiction as a network of such family resemblances, it is easier to see that science fiction is not one thing. Rather, it is any number of things - a future setting, a marvellous device, an ideal society, an alien creature, a twist in time, an interstellar journey, a satirical perspective, a particular approach to the matter of story, whatever we may be looking for when we look for science fiction,

Revista de Letras JUÇARA, Caxias - Maranhão, v. 02, n. 01, p. 153 - 167, jul. 2018|159 
here more overt, here more subtle - which are braided together in an endless variety of combinations. (KINKAID, 2008, p. 20-21)

Following this logic, if one work of fiction has one trait, one resemblance, which in some moment was attributed to Sci-fi, then this work is surely Sci-fi. This approach is very broad, but manages to comprehend the whole body of Science fiction without commiting any injustice. At the same time, acknowledging that fictional works are complex entities, formed by inumerous particular traits, Kinkaid's thinking also gives way to the multiplicity of genres in the same work, which may concern different, although sometimes related, genres. That's the point of Tzvetan Todorov, who argues that it is better to say that a genre, or genres, is manifested in a given work, and not the contrary (1975). In the same way, considering genres as such tightly related structures, the question of their origins, according to the author, is also dependable: "A new genre is always a transformation of one or several old genres: by inversion, by displacement, by combination" (1976, p. 161).

It is possible to apply the above referred approaches to Gothic and Sci-fi, and particularly to Frankenstein. Therefore, Shelley's novel belongs both to Gothic, due to the aspects previously mentioned, and to Science fiction, due to its interest in the scientific field through fiction, as it will be later specified. Furthermore, Frankenstein may be considered the turning point in which the early examples of Sci-fi books, recognized as such, emerged, through developments of the Gothic genre; although it would be precipitate to consider it the founder of the genre, since Sci-fi later evolved beyond its first established traits. Ultimately, Gothic and Science fiction, in Frankenstein and other works, share common aspects, especially the questioning of rationality, as Brantlinger defends in his "The Gothic Origins of Science Fiction", suggesting that "the conventions of both Gothic and science fiction involve a rejection or a symbolic putting to sleep of reason (...) (1980, p. 31). Now Frankenstein's antecipation of the Sci-fi genre is left to be examined, as well as its important influence in fiction.

\section{FRANKENSTEINS SCIENCE FICTION LEGACY}

Going back to the genesis of Frankenstein, several scientific influences 
are observable, besides the Gothic already mentioned. To begin with, the disussion concerning the nature of life and its creation in the Summer of 1816 was very important for the intent of writing a ghost story; it was the uncanny background needed for the story to achieve its final effect. In her Preface for the third edition of the book, Mary Shelley notes:

\begin{abstract}
Many and long were the conversations between Lord Byron and Shelley, to which I was a devout but nearly silent listener. During one of these, various philosophical doctrines were discussed, and among others the nature of the principle of life, and whether there was any probability of its ever being discovered and communicated. They talked of the experiments of Dr. Darwin, (...) who preserved a piece of vermicelli in a glass case, till by some extraordinary means it began to move with voluntary motion. Not thus, after all, would life be given. Perhaps a corpse would be reanimated; galvanism had given token of such things: perhaps the component parts of a creature might be manufactured, brought together, and endued with vital warmth. (SHELLEY, 2005, p. 356-57)
\end{abstract}

Erasmus Darwin (1732-1802) (Charles Darwin's grandfather) was much admired by Percy Shelley, who transmitted his enthusiasm to his wife (Florescu, 1998, p. 189). His experiments related to the properties of electricity as a principle of creation were related to those of Italian physicist Luigi Galvani (1737-1798), who was famous for having produced movement in frogs through a relation between electrical shocks and the nervous system of the animals (FLORESCU, 1998, p. 188). Galvanism is indeed the main scientific theorical path followed by Victor Frankenstein in the story, the principle through which the experiment ultimately functions, yet it is only mentioned in the third edition. Although by her Preface one could assume that Mary Shelley's interest in science was born on that day, when researching on her life it is easy to notice that the author already had some acquaintece with the matter; instead the spooky and stormy day served as the final touch in which all came together-fictional imagination and scientific hypothesis.

The work of another man of science, for example, Sir Humphry Davi, was important for Mary to define the idea of modification of nature, crucial to Victor's character (SCHOR, 2003). Davi belonged to William Godwin's circle, Mary Shelley's father, and thus was a constant presence in their household. This was due to Godwin's practice of educating his daughter and other children at home, where "knowledge, scientific as well as literary, were equally available" (SCHOR, 
2003, p. 29). William Godwin himself-a controvertial writer on his time due to his radical writings about individual emancipation--may be said to have served as an important influence to his daughter through his writings, especially the ones concerning occultism. Mary printed his book Life of the Necromancers in 1834, which portrays some alchemists who are mentioned in Frankenstein, such as Cornelius Agrippa, much admired by Victor and of fundamental importance to the opposition between old "scientific" practices and the present reality the character lives in.

Mary Shelley, thus, had undoubtly some scientific background, which properly fit with Gothic conventions. This pioneering junction is still more evident when the nomenclature to science is closely considered. The term "science" would only acquire its modern meaning through the nineteenth-century; although the term already existed in the English language since the Middle Ages, it was first considered a mere synonym to "knowledge". In the course of time, science "stood for a particular kind of knowledge-firmer and less fallible knowledge" (ROSS, 1962, p. 67-68). Indeed, in Frankenstein, scientists are still called "natural philosophers" and the field Victor deepens his studies is consequently natural philosophy? ${ }^{2}$.

The book is thus set in a crossroads, in the start of the scientific expansion that would dominate the century and define modern science. This struggle can be felt in the inclination Victor feels for the metaphysical ambition of the outdated authors of the past, in opposition to the practices of modern science. In Victor's vision, when studying modern science, he "was required to exchange chimeras of boudless grandeur for realities of little worth" (SHELLEY, 2005, p. 75). Victor preserves the ambition of old alchemists in an age in which the studies of nature, later to be called "sciences", are suffering an important paradigm of progressively losing these ambitions. At the same time, considering that the Monster is the product of a growing modern science, there is also a critique to the limits of this evolving practice, which, in Shelley's book, culminates with the scientific usurpation of a fundamentally natural process: the creation of life.

The fact that this formula created by Shelley--the scientist struggling with

\footnotetext{
2 In every occasion that the terms "science", "scientist" or "scientific" are referred in this article in relation to Shelley's book, it must be considered an usage made in retrospect.
} 
his desires-became particularly recurrent in nineteenth century works, such as Robert Luis Stevenson's The Strange Case of Dr. Jekyll and Mr. Hyde and H. G. Wells's The Island of Doctor Moreau, shows the importance of Shelley's insight into the discussions to come. In Stevenson, scientific ambition causes Dr. Jekyll's inmost tendencies to emerge and personify themselves in the figure of Mr. Hyde, who, as the Monster, represents its master's double, ultimately causing destruction. In Wells the effect is the same, only with a more solid scientific background that would later dominate the Sci-fi genre: Dr. Moreau is pushed away from society due to his subversive experiments in which animals are vivisected and hypnotized, in order to become "humans"; however, the so called Beast People constantly return to their original animal form, consequently turning against their master.

It is not an overstatement to call Victor Frankenstein the father of these and many other scientist figures of later Gothic and Sci-fi literature. That does not necessarily mean, however, that Frankenstein is the father of all Sci-fi. Returning to Kinkaid's perspective, no Sci-fi work is able to contain all the meaning the genre can express. What this article intends to argue, instead, is that Frankenstein, or the Frankestenian scientist, may be assuredly placed as the the main influence to the line of works which would culminate in the properly called Science fiction genre. Since the genre was established, however, many other relations could be made to works even previous to Shelley's masterpiece, still within the borders of Sci-fi.

Being the first in the tradition of the mad scientists, Shelley's novel accordingly lacks many of the scientific precision which would be evident in later writers/scientists such as H. G. Wells. When Victor discovers the "secret" of creation, for example, the author relies more on a literary rather than scientific language:

I paused, examinig and analysing all the minutiae of causation, as exemplified in the change from life to death, and death to life, until from the midst of this darkness a sudden light broke in upon me - a light so brilliant and wondrous, yet so simple, that while I became dizzy with the immensity of the prospect which it illustrated, I was surprised that among so many men of genius who had directed their inquiries towards the same science, that I alone should be reserved to discover so astonishing a secret. (SHELLEY, 2005, p. 79-80) 
Although later on Victor explains that any specification could not be made, should others follow the same path he had, the reader must remember that Mary Shelley--even having the set of influences already mentioned--was only an enthusiast of the subject she was depicting. The same is observable in the moment of the Monster's awakening:

It was on a dreary night of November that I beheld the accomplishment of my toils. With an anxiety that almost amounted to agony, collected the instruments of life around me, that I might infuse a spark of being into the lifeless thing that lay at my feet. It was already one in the morning; the rain pattered dismally against the panes, and my candle was nearly burnt out, when, by the glimmer of the half-extinguished light, I saw the dull yellow eye of the creature open; it breathed hard, and a convulsive motion agitated its limbs. (SHELLEY, 2005, p. 84-85)

In this excerpt, the vague and poetic expressions "instruments of life" are referred about the way of creating the Monster, which, added to Victor's visit charnel houses to collect bones, in the previous chapter, are the only few exemples of how science is dealt with in the first edition of the book. This lack of scientific fact, however, must not be seen as a flaw of the book. Observing Frankenstein's legacy, it is evident that its main contributions to Sci-fi go beyond the mere depicting of scientific fact, although this aspect was refined by later writers from within the realm of science. Taking advantage of the already established Gothic convention of the irrational, Shelley created the "anti-scientific pessimism" (BRANTLINGER, 1980, p. 32), which become the most recurrent aspect through Sci-fi in any medium. Science is always brought, in this sense, as a warning to what its mishandling can cause; since its development is inevitable, a consequence of evolution, its questioning must follow along.

Besides that, Frankenstein breathes science, or natural philosophy, through all its pages. Science is present in the crucial moments of the story, and its consequences are felt even when it is not mentioned by its name, in the figure of the created Monster, its anguish and destruction. There is no way, hence, to consider Shelley's novel placed out of the Sci-fi genre, since it constituted its first developments. And at the same time, however, there is no doubt that Frankenstein's legacy has grown far outside the borders of Shelley's initial "hideous progeny". 


\section{CONCLUSION}

From the multiple influences of its origins to the legacy left in literature as a whole, Mary Shelley's Gothic/Sci-fi novel Frankenstein expanded beyond genre borders. Gothic is fundamental for the atmosphere and thrilling fear caused by the irrationality of the Monster; while Sci-fi reinforces the threatening aspect of the book, the possibility of its creation. In this sense, the story also exemplifies the discussion about the origin and evolution and genres, showing that literature, as a human practice, tends to be flexible concerning its themes and its placing in different genres, which, by they turn, may also share common elements without losing their peculiarities. As Todorov claims, a single work of fiction may manifest different genres (1975), which will all contribute to its themes and message. Frankenstein, then, both deals with Gothic sensations and techniques of suspense as with Science fiction speculation and pessimism, antecipating the formation of the latter genre.

Finally, Frankenstein, besides being a literary text subject to its placing in different genres, is also a modern myth. This is no novelty, since the novel itself is based on myths, namely, the myth of creation from the Genesis and Milton's Paradise Lost (a book the Monster reads) and the Promethean myth, both of which reflect the relation between transgression and punishment (ZIOLKOWSKI, 1981). The book is a double like Frankenstein and its Monster in several ways. It is a literary text, with all its particular features; but it is also an enduring myth, whose scientist-creation relationship turned out to be intimately related to its age of fast scientific evolution-and is fated to be ever present as long as scientific practices are questioned.

\section{UMA CONVERGÊNCIA DE GÊNEROS: GÓTICO E FICÇÃO CIENTÍFICA EM FRANKENSTEIN}

Este trabalho tem por finalidade analisar a romance Frankenstein, de Mary W. Shelley, sob uma perspectiva de gêneros literários. Acredita-se que a obra manifesta tanto traços do genêro Gótico devido à sua estrutura e temáticas comuns ao período em que foi publicada -, quanto elementos do que viria a se chamar o gênero da Ficção científica, todos os quais são aqui analisados dentro da obra e no contexto de sua criação. Nesse sentido, há uma convergência de gêneros em ação, ainda que um deles esteja aí em forma nascente: o romance de Shelley antecipa um interesse 
científico dentro da ficção que viria a se especificar, a partir de seu legado. A perspectiva de Tzvetan Todorov é considerada, uma vez que ela defende uma relação de múltiplos gêneros numa mesma obra, assim como a criação de gêneros literários a partir de outros já existentes. Concluise que o romance manifesta elementos suficientes para abranger os dois gêneros discutidos, os quais tanto coincidem quanto diferem.

Frankenstein. Gótico. Ficção científica. gêneros literários.

\section{REFERENCES}

BALDICK, Chris. In Frankenstein's Shadow: Myth, Monstrosity and Nineteenthcentury Writing. Oxford: Clarendon Press, 1987.

BRANTLINGER, Patrick (1980). "The Gothic Origins of Science Fiction". In: NOVEL: A Forum on Fiction, Vol. 14, No. 1, p. 30-43.

FLORESCU, Radu (1998). Em Busca de Frankenstein: o Monstro de Mary Shelley e Seus Mitos. Translated by Luiz Caros Lisboa. São Paulo: Mercúrio.

FREUD, Sigmund (1976). "O Estranho" In: Edição Standard Brasileira das obras psicológicas completas de Sigmund Freud. Vol XVII (1917-1919). História de uma neurose infantil e outros trabalhos. Traslated Jayme Salomão et al. Rio de Janeiro: Imago.

GERNSBACK, Hugo (ed.) (1926). Amazing Stories. Vol. 1. № 1. New York: Experimenter Publishing Company.

HEILMAN, Robert B. (1967). "Charlotte Brontë's 'New' Gothic". In: RATHBURN, C. Robert; STEINMANN, Martin (Orgs.). From Jane Austen to Joseph Conrad: Essays Collected in Memory of James T. Hillhouse. Minneapolis: University of Minnesota Press. (p. 118-32).

JAMES, Edward; MENDLESOHN, Farah (Orgs.) (2003). The Cambridge Companion to Science Fiction. New York: Cambridge University Press.

KINCAID, Paul (2008). "On the Origins of Genre". In: What it is We Do When We Read Science Fiction. Essex: Beccon Publications. p. 13-21.

LEVINE, George; Knoepflmancher, U. (Orgs.) (1982). The Endurance of Frankenstein: Essays on Mary Shelley's Novel. Berkeley: University of California Press.

PUNTER, David (2013). The Literature of Terror. Vol. 1. $2^{\text {nd }}$ ed. New York: Routledge.

RANK, Otto (2014). O duplo. [E-book]. Dublinense. Kindle edition. 
ROSS, Sydney (1962). "Scientist: The Story of a Word". In: Annals of Science, Vol. 18, № 2, p. 65-85.

SEDGWICK, Eve Kosofsky (1986). The Coherence of Gothic Conventions. New York: Methuen.

SCHOR, Esther (Org.) (2003). The Cambridge Companion to Mary Shelley. Cambridge: Cambridge University Press.

SHELLEY, Mary W. Frankenstein; or, The Modern Prometheus: The 1818 version, Second Edition. (Edited by D. L. Macdonald \& Kathleen Scherf). Peterborough: Broadview Literary Texts, 2005.

STEVENSON, Robert L. Strange Case of Dr. Jekyll and Mr. Hyde, and Other Tales (Edited by Roger Luckhurst). Oxford: Oxford World's Classics, 2006.

SUVIN, Darko (1972). "On the Poetics of the Science Fiction Genre". In: College English, Vol. 34, No. 3, p. 372-382.

TODOROV, Tzvetan (1975). Introdução à Literatura Fantástica. Translated by Maria Clara Correa Castelo. São Paulo: Perspectiva.

(1976). "The Origins of Genres", In: New Literary History, Vol. 8, No. 1, Readers and Spectators: Some Views and Reviews, p. 159-170.

WATT, James (2004). Contesting the Gothic: Fiction, Genre and Cultural Conflict, 1764-1832. Cambridge: Cambridge University Press.

WELLS, H. G. (2002). The Island of Doctor Moreau. New York: The Modern Library.

ZIOLKOWSKI, Theodore (1981). "Science, Frankenstein and Myth". In: The Sewanee Review Vol. 89, No. 1 , p. 34-56.

Data da Submissão: 25/02/2018

Data da Aprovação: 24/07/2018 